\title{
Editorial
}

\section{The interface of leisure and retail property markets: From leisure to the retail leisure mix}

This issue of the Journal of Leisure Property is, in your editor's view, a memorable one. First, after eight issues sufficient material has been published to make it possible to reflect on some of the themes that have been at the forefront of discussion within leisure property circles over recent years. It can therefore be argued that we have reached a point of maturity at which a contribution to debate and practice can begin to be assessed. We hope that, over the coming issues, authors will begin to critique and build on the themes that have been debated within the Journal.

Secondly, it is a moment that heralds change. In reflecting on the success and the direction of the Journal, a decision has been made to extend its remit explicitly to include retail property. So, from the next issue, it will be published under a new name:

Journal of Retail \& Leisure Property. This move has been prompted, in part at least, by recognition of the synergy between retailing and leisure activities that is being successfully exploited by developers in many instances and across continents. As the demands of retail customers become ever more driven by concepts of service and ambience, so the retailer and retail developer seek to retain footfall, partially at least by maintaining retailing as a 'people' activity — and not something dominated by electronic transaction. Consequently, in this Editorial an attempt will be made to adopt a 'Janus' perspective, by looking back at some of the issues that have been covered as well as reviewing the directions that the Journal is seeking to take.

\section{LEISURE: A BUSINESS OPERATOR PERSPECTIVE}

The integration of leisure within the retail offer and the introduction and successful exploitation of retail within the leisure offer indicate the very real need for property professionals to develop a deep understanding of the operator perspective, in both leisure and retail terms. This is something that the Journal is uniquely placed to do. Indeed, this issue, in common with most of its predecessors, has a mix of papers that enable a clearer understanding of the needs of the business operator to be developed. They also develop a common theme of ensuring the leisure offer is promoted and managed in ways that maximise the profitability. Ibrahim and $\mathrm{Ng}$ in their analysis of success factors for 
Singaporean shopping centres present evidence that ease of transport to the centre and the entertainment features within the centre are both critical in ensuring long-term viability in a saturated market. In a different context, and within a different continent, the underlying message of Monteson and Singer is similar. They argue that the rise of the health-conscious and economically empowered American provides opportunities to add profit to hotel businesses by the addition of spa facilities. However, they point out that the ingredients for success lie in schemes that are well-conceived, appropriately themed, appropriately designed and marketed and well managed. This analysis demonstrates just what similarities exist between retail and leisure.

The similarities so identified perhaps go to the heart of an issue that has dogged the leisure sector for so long, namely, that of definition. Just what is included within it? The definition that has been adopted by the Journal has been to embrace within its remit a wide range of leisure offers. The result has been that it has covered aspects of leisure property as diverse as the effective management of public park lands to an analysis of success factors for shopping centres and from hotels and vacation time-share design and development to aspects of appraisal of multiplex cinemas and eating houses. Arguably, the content of the Journal already does recognise the integrated nature of leisure and retail and so the move to officially recognise this interdependence is seen to be a logical progression in meeting the needs of you, the reader.

\section{APPRAISING THE LEISURE AND RETAIL OFFER}

The appraisal of leisure property has always been integrated with aspects of management and required the appraiser or valuer to appreciate the relationship between property values and the business entity. As most standard texts on the subject demonstrate, ${ }^{1}$ the relationship between market value and trading accounts is inextricably linked. This is also recognised in professional valuation standards. ${ }^{2}$ However, although at a superficial level the market value of a leisure property is normally assessed in relation to trading patterns, the rise of global corporatism has made analysis for appraisal purposes a much more complex exercise. Nowhere in the Journal has this been more clearly expressed than in the paper in $J L P 2 / 2$ by Nilsson, Harris and Kett on valuing hotels as business entities. The value of brand within the appraisal process is an ongoing debate that is likely to continue to concern the readership and the introduction of retail property within the Journal's remit provides the scope for this. Under UK convention, the valuation of retail property is normally undertaken in relation to size ${ }^{3}$ and this concept has recently been extended to many leisure units. However, the disconnection between trading receipts and property values can lead to issues which threaten trading viability and the sustainability of property valuers, as argued by Sayce, Smith and Walker in their paper on multiplex cinemas in $J L P 1 / 4$. 
Future papers debating the interface between appraisal and commercial viability will be welcomed.

\section{PLANNING AND DEVELOPMENT: THE NEXT GENERATION OF LEISURE AND RETAIL PROPERTIES}

The decision to integrate retail within the Journal is entirely appropriate when viewed in relation to land use planning issues. Indeed, within the UK, there is ambivalence in planning terms, with many leisure properties being classified as a sub-set of retail ${ }^{4}$ and, indeed, planning matters have exercised our authors perhaps more than any others and this issue is no exception to this general rule.

The planning debate has been extremely topical within the UK over the last year, with the publication almost 12 months ago of the government's intention to carry out a systematic and fundamental review of the land use legislation. ${ }^{5}$ The strict planning regime, inevitably given the high density of development within the UK, produces tensions, as illustrated by Ennis-Reynold's paper on multiplexes. However, the issue extends beyond planning regulation to retail sales of alcohol, with proposals for an overhaul of this system too, including its possible integration with planning. ${ }^{6}$

In some other countries, where land is less of a premium, the regulatory framework is less of an issue. However, assessing development potential is a matter of concern wherever new offers are in prospect and, in this issue, two papers contribute to the debate, both referring to the hotel market. The viability of the hotel sector has come in for especial scrutiny since September 11, but both Nichols, writing in respect of the mid-level US hotel sector, and Beckley, who analyses the potential of the Canadian hotel market, see signs for optimism, as the memories of the atrocity fade. However, both were written before the latest terrorist outrage in Bali on 12 October 2002. The uncertainty and despondency that this is likely to evoke among tourist and leisure operators will take time to assess, but undoubtedly will evoke a response through the Journal. Future papers dealing with all aspects of leisure and retail funding, financing and development, including the regulatory framework, would be welcomed.

\section{TOWARDS THE BETTER UNDERSTANDING OF SUSTAINABLE DEVELOPMENT ISSUES}

The theme of sustainable development is one that has gained in importance as the Journal has developed; with increasing recognition among the corporate and investment communities of the need to balance social and environmental considerations in order to exploit fully economic returns, it is likely to gain even greater prominence. ${ }^{7}$ The ways that authors have so far addressed this agenda have been varied but include social issues ranging from Walker's examination of culture and leisure (JLP 1/1) to Barnes's paper $(J L P 2 / 2)$ on the need to provide leisure opportunities for an ageing population. 
The recent Summit in Johannesburg may not have succeeded in moving forward on a consensus as to the practice of sustainable development, but the ambitions to do so remain. Perhaps more pertinent to the readership of this Journal is the integration of these ambitions into governmental policy. Ennis-Reynolds, in her paper on the relationship between sustainable development and multiplexes, clearly demonstrates just how difficult it can be to predict the effect of such policies. She argues, for example, that while the implementation of recent planning guidance has resulted in leisure developments moving in-town, thereby helping to achieve government ambitions in respect of town-centre vitality, it may also, paradoxically, have created new barriers for the less mobile members of society. The challenge to developers and all property professionals is clear: the need to address social concerns is now an integral part of achieving consent for and successful exploitation of development opportunities.

In a different guise, the sustainability theme is taken up by Bulley, in his intriguing paper on football stadia. In this he argues that the location and financing of stadia are now inextricably bound up in the debate regarding the regeneration and revitalisation of town centres.

\section{SUMMARY}

From this analysis of the current issue and a selective overview of previous papers the decision to widen the scope of the Journal becomes clear. While trading is not an essential characteristic of leisure property, it is inherent in most - be they operating for profit, as is the case of hotels, clubs and bars - or in pursuance of other community and sporting goals. The Journal will continue to include contributions in respect of all forms of leisure property development, but the ambiguity between retailing goods and services and the trading of leisure experiences will, with our next issue, be removed. The agenda for both retail and leisure is in many ways the same. We look forward to our authors taking up the new mantle and continuing to add to the industry debates.

Sarah L. Sayce October 2002

\section{References}

1. See, for example, Rushmore, S. and Baum, E. (1999) Hotels \& Motels: Valuations and Market Studies, Appraisal Institute, Chicago, USA; Marshall, H. and Williamson, H. (1996) (Eds) Law and Valuation of Leisure Property, Estates Gazette Ltd, London, UK.

2. Both the RICS, in their Appraisal and Valuation Standards and the International Valuation Standing Committee in their International Valuation Standards recognise the revenue approach to establishment of market values.

3. For readers not familiar with retail valuation, within the UK and other European countries retail rental values are normally established in respect to the size of the unit on the assumption that the value decreases with depth. Hence, units are 'zoned', normally using three-metre depths with a principle of Zone A being worth double Zone B, etc. For larger units, zoning is not adopted and an overall square-metre approach is used. This 
methodology is now widespread for the appraisal of many leisure units, such as cinemas and bowling alleys.

4. The Use Classes Order, 1973, although currently under review, classifies restaurants and bars as a sub-set of retail (Class A), while a bar within a multiplex cinema is classified in the D group of users (assembly and leisure), and other leisure properties are not included in any classification.

5. Department of Transport, Local Government and the Regions (2001) Planning Green Paper - Planning: Delivering a Fundamental Change, DTLR, London, UK.

6. The UK government has announced intentions to legislate on the licensing laws and a draft bill is widely expected this autumn. This issue has recently been debated by the Leisure Property Forum in their publication Reforming Leisure Licensing Reform: The Implications for Property, LPF, London, UK.

7. The growth of the corporate social responsibility agenda (see, for example, Welford (2000) Corporate Environmental Management: Towards Sustainable Development, Earthscan, London, UK) and the success of sustainable investment indices, such as the Dow Jones sustainability index and the FTSE4Good Index, all point to the recognition by business that sustainability is a business concern. 